\title{
IMPLEMENTASI KEBIJAKAN PENANGGULANGAN KEMISKINAN MELALUI KURMIKRO PT. BRI UNIT SOEKARNO-HATTA KOTA MALANG
}

\author{
Buyung Adi Dharma, Sumartono, Sarwono \\ Program M agister IImu A dministrasi Publik, U niversitas B rawijaya, JI. V eteran M alang \\ Email. buyung.adidharma89@ gmail.com
}

\begin{abstract}
ABSTRAK
Latar belakang penelitian ini adalah masih adanya permasalahan kemiskinan di Indonesia membutuhkan penanganan dari pemerintah untuk segera ditanggulangi. Perpres No. 15 Tahun 2010 tentang percepatan penanggulangan kemiskinan menjadi kebijakan yang secara khusus mengatur tentang percepatan penanggulangan kemiskinan, dimana diantaranya memuat tentang kebijakan pemberian K redit U saha Rakyat bagi pelaku usaha di Indonesia. Penelitian ini sebagai kajian khusus terhadap PT. BRI U nit Soekarno-Hatta kota M alang. Metode penelitian yang digunakan adalah metode kualitatif dengan pendekatan deskriptif. Hasil penelitian ini menunjukkan bahwa kinerja PT. BRI Unit Soekarno - Hatta dalam implementasi kebijakan Kredit U saha Rakyat M ikro ditinjau dari aspek isi dan lingkungan dari kebijakan menunjukkan hasil yang sangat baik. Faktor yang mendukung adalah karakteristik PT. BRI Persero Tbk yang merupakan profesional dibidang perbankan. Permasalahannya adalah keterbatasan PT. BRI Persero Tbk dalam melakukan kegiatan monitoring dan evaluasi atas pengentasan kemiskinan sesuai dengan tujuan dari Peraturan Presiden N o. 15 Tahun 2010. Kebijakan KUR M ikro membawa dampak yang positif bagi laju ekonomi dan usaha UM KM. PT. BRI dalam penyaluran KUR Mikro dengan target yang tinggi akan meningkatkan resiko terjadinya kerugian akibat munculnya kredit macet sehingga untuk menghindarinya maka permohonan kredit harus dinilai oleh sesuai profesionalisme lembaga perbankan.
\end{abstract}

Kata Kunci: I mplementasi kebijakan, Penanggulangan kemiskinan, K redit U saha rakyat.

\begin{abstract}
Background of this study is the poverty problems in Indonesia requires the government concern to immediately addressed. Presidential Decree No. 15 Year 2010 on the acceleration of poverty reduction is a policy that specifically regulates the acceleration of poverty reduction, which among others includes about micro business credit policies for micro businesses in Indonesia. This research as a special study on PT. BRI Unit SoekarnoHatta Malang. The method used is qualitative method with descriptive approach. The results are indicate that PT. BRI Unit Soekarno - Hatta in policy implementation micro busines credit in contents and context aspects of the policy showed excellent results. Supporting factors is characteristic of PT. BRI Persero Tbk, which is a professional in the field of banking. The problem is PT. BRI Persero Tbk cant conducts monitoring and evaluation of poverty reduction in accordance of Presidential Decree No. 15 Year 2010 goals. This policy bring positive impact to target groups. Implementation with a high target would increase the risk of losses due to the rise of bad loans so as to avoid, the application for credit must be assessed by appropriate professionalism banking institutions.
\end{abstract}

Keywords: Policy implementation, Poverty reduction, Micro Business Credit 


\section{PENDAHULUAN}

Kemiskinan merupakan persoalan yang mengakar di negara Indonesia. Berbagai kebijakan dan strategi dalam setiap era pemerintahan telah dilakukan hampir oleh semua pemimpin negeri ini namun tidak pernah menemukan hasil yang memuaskan, sehingga kemiskinan sampai saat ini masih mendera bangsa ini. $M$ asalah kemiskinan, pengangguran dan kesenjangan, jika tidak ditanggulangi dengan serius dan menyeluruh akan berdampak pada permasalahan sosial yang lain.

Pada tahun 2010 presiden mengeluarkan kebijakan publik yaitu Peraturan Presiden No 13 tahun 2009 tentang koordinasi penanggulangan kemiskinan kemudian dilanjutkan peraturan Presiden No 15 tahun 2010 tentang percepatan penanggulangan kemiskinan, Intruksi Presiden No 1 tahun 2010 tentang percepatan prioritas pembangunan nasional tahun 2010 dan Inpres No 3 Tahun 2010 tentang program pembangunan yang berkeadilan.

Beberapa upaya yang tengah dilakukan oleh pemerintah Indonesia adalah dengan menggerakkan sektor real melalui sektor UMKM. U paya strategis yang dapat dilakukan dalam rangka pemberdayaan UMKM antara lain; menciptakan iklim yang kondusif bagi pengembangan UMKM meliputi regulasi dan perlindungan usaha; menciptakan sistem penjaminan bagi usaha mikro; menyediakan bantuan teknis berupa pendampingan dan bantuan manajerial, dan; memperbesar akses perkreditan pada lembaga keuangan. Dengan empat langkah tersebut, maka sektor UMKM akan lebih berdaya yang pada akhirnya akan berakibat pada pengurangan jumlah angka kemiskinan. Salah satu program pemerintah dalam meningkatkan akses pembiayaan UMKM kepada perbankan dengan pola penjaminan yaitu $K$ redit Usaha Rakyat (KUR) yang mulai diluncurkan pada N ovember 2007.
Lingkungan di sekitar jalan Soekarno-Hatta, kecamatan Lowokwaru, kota Malang yang merupakan pusat keramaian Universitas B rawijaya, menimbulkan bermunculannya unit-unit usaha kecil dan mikro untuk mencukupi kebutuhan dari pelajar dan penduduk sekitar jalan Soekarno-Hatta. Mengingat kebijakan KUR Mikro memiliki sasaran kepada pemberdayaan unit usaha kecil dan mikro, maka dirasa layak untuk diteliti lebih lanjut implementasi KUR Mikro pada BRI unit Soekarno-H atta.

PT. Bank Rakyat Indonesia (Persero) Tbk, sebagai salah satu bank pemerintah (BUMN), sebagai pelaksana penyaluran kebijakan $\mathrm{K}$ redit $\mathrm{U}$ saha $\mathrm{R}$ akyat memiliki catatan realisasi terbesar dibandingkan dengan bank pelaksana lainnya, dengan total plafond mencapai Rp. 115,6 triliun. Selain sektor ritel BRI juga menyalurkan KUR di sektor mikro yang masing-masing plafondnya sebesar Rp. 20,6 triliun dan Rp. 95 triliun, dengan jumlah debiturnya sebanyak 117.259 UK M dan 11.326.246 UKM, rata-rata kredit mencapai Rp. 175,7 juta/debitur untuk sektor ritel dan Rp. 8,4 juta/debitur untuk sektor mikro, serta NPL penyaluran masing-masing sektor sebesar 2,9\% dan $1,8 \%$.

Menurut Solihin (2008 : 179), implementasi kebijakan dipandang sebagai satu proses tindakan administrasi dan politik. Keberhasilan atau kegagalan implementasi dapat dievaluasi dari sudut kemampuannya secara nyata dalam mengoperasikan program yang dirancang. Sebaliknya keseluruhan proses implementasi dapat dievaluasi dengan cara mengukur atau membandingkan antara hasil program dengan tujuan kebijakan.

Grindle, 1980, dikutip oleh Solihin (2008: 180) mengatakan bahwa proses implementasi kebijakan hanya dapat dimulai apabila tujuan dan sasaran yang semula bersifat umum telah diperinci, program aksi dan sejumlah dana telah dialokasikan untuk mewujudkan tujuan dan sasaran, tanpa adanya syarat tersebut 
kebijakan publik hanya dikatakan sekedar retorika politik atau slogan politik.

Implementasi kebijakan publik menurut Nugroho (2012 : 674) dapat langsung diimplementasikan dalam bentuk program dan langsung dapat dioperasionalkan antara lain (K eppres, inpres, Pepres dll). Kelompok-kelompok program diatas menurut Solihin (2008: 28) adalah sebagai kebijakan pemerintah yang dimaksudkan menyelesaikan persoalan kemiskinan dengan suatu lingkup kegiatan pemerintah yang relatif khusus dan cukup jelas batas-batasnya menyangkut kegiatan pengesahan/legislasi, pengorganisasian dan pengerahan sumberdaya yang diperlukan, $M$ asalah-masalah implementasi yang kadang muncul tidak sesuai konsep dan ancaman utama adalah konsistensi. Nugroho (2012 : 681) menyampaikan bahwa rencana adalah $20 \%$, implementasi $60 \%$, sisanya $20 \%$ mengendalikan implementasi.

K eberhasilan implementasi menurut Grindle (1980) dipengaruhi oleh dua variabel besar, yakni isi kebijakan (content of policy) dan lingkungan implementasi (context of implementation). $\checkmark$ ariabel isi kebijakan mencakup: 1) sejauh mana kepentingan kelompok sasaran termuat dalam isi kebijakan; 2) jenis manfaat yang diterima oleh target group; 3) sejauh mana perubahan yang diinginkan dari sebuah kebijakan; 4) apakah letak sebuah program sudah tepat; 5) siapa pelaksana program; 6) sumberdaya yang dikerahkan untuk pelaksanaan program.

Sedangkan $V$ ariabel lingkungan kebijakan mencakup: 1) seberapa besar kekuasaan, kepentingan, dan strategi yang dimiliki oleh para aktor yang terl ibat dalam implementasi kebijakan; 2) karakteristik institusi dan rezim yang sedang berkuasa; 3) tingkat kepatuhan dan responsivitas kelompok sasaran.

Kesembilan variabel ini menjadi bahan analisa kritis dalam melakukan penelitian mengenai implementasi kebijakan penanggulangan kemiskinan di Kota Malang melalui Kebijakan
Penyaluran KUR Mikro oleh PT. Bank Rakyat Indonesia, kantor unit Soekarno$\mathrm{H}$ atta M alang.

\section{KAJIAN TEORI}

\section{Kebijakan Publik dan Implementasi Kebijakan Publik.}

Kebijakan publik dalam pandangan umum sering diartikan sebagai serangkaian peraturan-peraturan, perudang-undangan dan aturan formal lainnya yang menjadi acuan dalam bertindak publik. Ada pula yang mengindentikkan kebijakan publik sebagai keberpihakan pemerintah terhadap suatu masalah/isu. Kebijakan publik dimaknai sebagai kebijakan yang dihasilkan dari produk politik atau hukum yang ditujukan sebagai saranan memecahkan masalah. M asalah yang harus diatasi pemerintah adalah masalah publik, yaitu nilai, kebutuhan, peluang, yang tak terwujudkan meskipun bisa diidentifikasi tetapi hanya mungkin bisa dicapai melalui tindakan publik (Dunn,1994: 58) dikutip oleh tachjan (2006).

Kuncinya adalah persoalan publik menjadi alasan pemerintah untuk melakukan sesuatu dan berbuat sesuatu karena keberadaaan pemerintah adalah sebagai pemegang mandat rakyat untuk mengelola negara. Hal ini juga sejalan dengan apa disampaikan oleh Hoogerweff (1983 : 9) sebagaimana dikutip oleh Tachjan 2006: "Fungsi sentral dari pemerintah adalah menyiapkan, menentukan dan menjalankan kebijakan atas nama dan untuk keseluruhan masyarakat di daerah kekuasaannya. (Hoogerwerf, 1983 : 9)"

Sedangkan mengenai Implementasi Kebijakan Publik, Edwards dan Sharkansky dalam Islamy, (1992: 18-19) mengatakan bahwa Implementasi kebijakan publik ditetapkan secara jelas dalam bentuk peraturan perundangan, pidato-pidato pejabat teras pemerintah atau pun dalam bentuk programprogram, proyek-proyek dan tindakan- 
tindakan yang dilakukan pemerintah. Karena implementasi merupakan perwujudan nyata dari (isi/tujuan) kebijakan publik, maka aktifitas-aktifitas implementasi haruslah dilakukan secara cermat. Rochyati (2011 : 22). Terdapat dua pilihan yang dapat diambil untuk mengimplementasikan kebijakan menurut Nugroho (2012 : 675) yaitu; 1). Langsung mengimplementasikannya dalam bentuk program-program atau; 2). M elalui serangkaian formulasi kebijakan derivat atau turunan dari kebijakan publik tersebut.

\section{Pemilihan Model Implementasi}

Keberhasilan implementasi menurut Grindle (1980) dipengaruhi oleh dua variabel besar, yakni isi kebijakan (content of policy) dan lingkungan implementasi (context of implementation). Variabel isi kebijakan ini mencakup : 1) sejauh mana kepentingan kelompok sasaran termuat dalam isi kebijakan; 2) jenis manfaat yang diterima oleh target group; 3) sejauh mana perubahan yang diinginkan dari sebuah kebijakan; 4) apakah letak sebuah program sudah tepat; 5) siapa pelaksana program; 6) sumberdaya yang dikerahkan untuk pelaksanaan program. Sedangkan V ariabel lingkungan kebijakan mencakup : 1) seberapa besar kekuasaan, kepentingan, dan strategi yang dimiliki oleh para aktor yang terlibat dalam implementasi kebijakan; 2) karakteristik institusi dan rezim yang sedang berkuasa; 3) tingkat kepatuhan dan responsivitas kelompok sasaran.

K esembilan variabel ini menjadi bahan analisa kritis dalam melakukan penelitian mengenai implementasi kebijakan penanggulangan kemiskinan di Kota Malang melalui Kebijakan Penyaluran KUR Mikro oleh PT. Bank Rakyat Indonesia, kantor unit Soekarno-Hatta $M$ alang, mengingat bahwa kebijakan KUR Mikro merupakan kebijakan yang tergolong strategis bagi upaya penanggul angan kemiskinan di Indonesia.

\section{METODE PENELITIAN}

Penelitian ini menggunakan jenis penelitian deskriptif dengan pendekatan kualitatif yang bertujuan untuk menggambarkan secara tepat tentang sifatsifat, keadaan, gejalasuatu individu ataupun kelompok tertentu, untuk menentukan frekuensi atau penyebaran suatu gejala gejala lain dalam masyarakat. Pemilihan pendekatan ini dengan tujuan untuk melihat fenomena tentang apa yang dialami oleh subjek penelitian secara menyeluruh.

Penelitian ini dilakukan di PT. Bank Rakyat Indonesia, kantor unit Soekarno-Hatta M alang aebagai pelaksana kebijakan pemberian $\mathrm{K}$ redit Usaha Mikro di wilayah Soekarno-Hatta kota malang. Observasi lebih lanjut dilakukan kepada pelaku usaha kecil mikro di lingkungan Soekarno-Hatta kota M alang.

Teknik analisa data yang digunakan dalam penelitian ini menggunakan model interaktif seperti yang digambarkan M iles dan Huberman, J ohnny Saldana (2014).

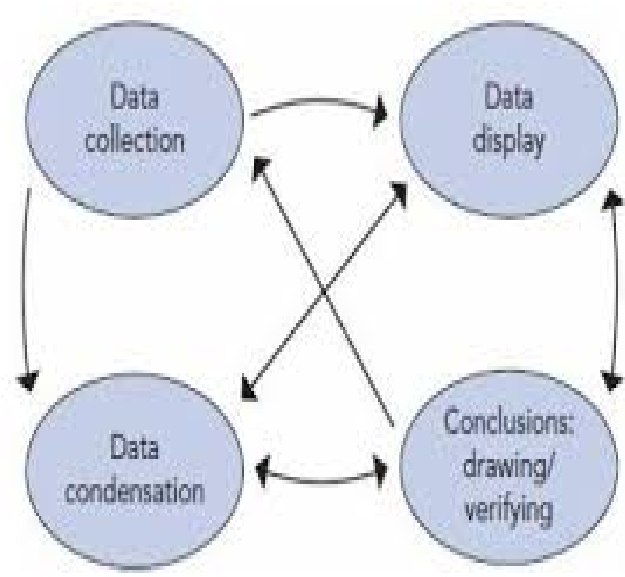

Gambar 1. Komponen A nalisis Data M odel Interaktif

Sumber: M iles M .B \& Huberman J ohnny Saldana (Q ualitative data analysis) 2014:33 


\section{HASIL DAN PEMBAHASAN}

$\mathrm{K}$ redit U saha Rakyat (KUR) M ikro adalah kredit/pembiayaan modal kerja dan atau investasi kepada debitur di bidang usaha sektor pertanian, perikanan, industri pengolahan, dan perdagangan yang terkait, yang produktif dan layak namun belum memenuhi persyaratan agunan tambahan Bank Pelaksana dengan plafon kredit sampai dengan R p.25.000.000,- (dua puluh lima juta rupiah) yang dijamin oleh Perusahaan Penjamin.Sumber dana penyaluran KUR Mikro adalah 100\% (seratus perseratus) dari dana Bank Pelaksana KUR Mikro. KUR Mikro disalurkan oleh Bank Pelaksana dan dijamin oleh Perusahaan Penjamin.

Mekanisme penyaluran KUR Mikro oleh Bank Pelaksana memiliki dua pola, yang pertama adalah pola penyaluran langsung dari Bank Pelaksana kepada U saha M ikro, dan yang kedua adalah pola penyaluran tidak langsung melalui lembaga linkage dengan pola channeling. Pola penyaluran KUR Mikro oleh BRI U nit Soekarno-Hatta kepada pelaku U saha Mikro menggunakan pola penyaluran langsung.

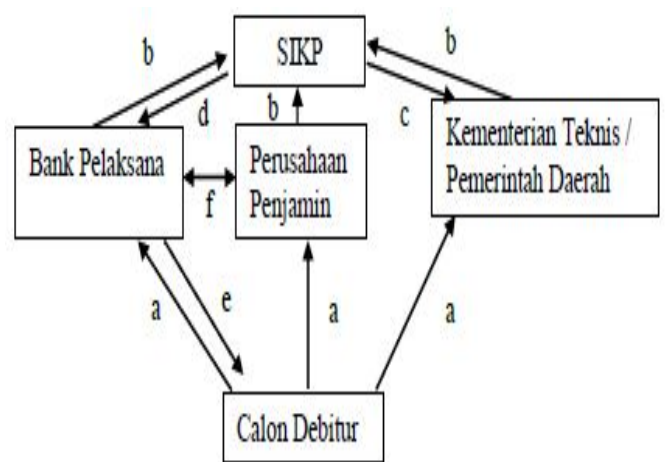

Gambar 1. Pola Penyaluran KUR Mikro Secara L angsung

Sumber: Data Permenko Ekonomi no 6 Tahun 2015 lampiran 1

Realisasi kebijakan KUR yang telah dilaksanakan oleh bank-bank pelaksana penyalur kebijakan KUR hingga bulan November tahun 2014 yang telah dilaporkan dan dipublikasikan oleh Komite KUR seperti pada tabel 1 .

Tabel 1. Realisasi dan NPL Penyaluran KUR Bank Nasional (31 November 2014)

\begin{tabular}{|c|c|c|c|c|c|c|}
\hline \multirow{3}{*}{ мо } & \multirow{3}{*}{ BANK } & \multicolumn{4}{|c|}{ REALISASI PENYALURAN KUR } & \multirow{3}{*}{$\begin{array}{l}\text { NPI } \\
(\%)\end{array}$} \\
\hline & & Plafon & Dutstanding & \multirow{2}{*}{ Debitur } & $\begin{array}{c}\text { Rata-rata } \\
\text { Kredit }\end{array}$ & \\
\hline & & (Rp Juta) & (kp juta) & & (kp juta) & \\
\hline 1 & BNI & 15.483 .835 & 3.239 .387 & 217.086 & 71,3 & 3,3 \\
\hline 2 & BRI (KUR Rinel) & 20.600 .695 & 7.821 .037 & 117.259 & 175,7 & 2,9 \\
\hline 3 & BRI (KUR Milko) & 95.003 .570 & 24.038 .639 & 11.326 .246 & 8,4 & 1.8 \\
\hline 4 & BANK MANDIRI & $17.464,110$ & 6.613 .257 & 385.93: & 45,3 & 3,4 \\
\hline 5 & DTN & 4.509 .002 & 1.007 .567 & 25.255 & 101,7 & 12,9 \\
\hline 6 & DUKOPIN & 1.013 .202 & 495.204 & $12.13 \mathrm{~s}$ & 149,4 & 5,5 \\
\hline 7 & BANK SYARIAH MANDIRI & 3.898 .017 & 1.145 .079 & 52.86: & 65,1 & 17,2 \\
\hline 8 & ENI SYARLAH & 312.702 & 134.670 & 1.424 & 224,5 & 4,6 \\
\hline & TOTAL & 159.173 .093 & 45.094 .920 & 12.145 .201 & 13,1 & 3,2 \\
\hline
\end{tabular}

Sumber: Data Realisasi Komite KUR yang diolah

Tabel 1 menunjukan bahwa realisasi KUR M ikro pada PT. BRI Persero di level nasional memiliki outstanding terbesar yaitu mencapai lebih dari 24 Trilliun rupiah dengan total debitur sebanyak 11.326.246 debitur. Dengan perolehan tersebut PT. BRI Persero masih dapat menjaga persentase NPL (Non Performing Loan/Total K redit $\mathrm{M}$ acet) KUR Mikro di level sehat (dibawah 3\%) yaitu $1,8 \%$.

Sedangkan untuk pencapaian BRI U nit Soekarno-H atta sebaga penyal ur K UR Mikro di wilayah Soekarno-Hatta Kota $M$ alang dapat dilihat di Tabel 2.

Tabel 2. Realisasi KUR Mikro BRI Unit Soekarno-Hatta (September$\mathrm{M}$ aret 2016)

\begin{tabular}{|c|l|c|c|}
\hline \multirow{2}{*}{ No } & \multicolumn{2}{|c|}{ Bulan } & \multicolumn{2}{c|}{ Realisasi } \\
\cline { 3 - 4 } & & $\begin{array}{c}\text { Jumlah } \\
\text { Debitur }\end{array}$ & $\begin{array}{c}\text { Jumlah Pencairan } \\
\text { (Rupiah) }\end{array}$ \\
\hline 1 & September & 32 & 520.000 .000 \\
\hline 2 & Oktober & 32 & 594.000 .000 \\
\hline 3 & November & 35 & 627.500 .000 \\
\hline 4 & Desember & 28 & 527.000 .000 \\
\hline 5 & Januari & 41 & 708.000 .000 \\
\hline 6 & Februari & 34 & 674.000 .000 \\
\hline 7 & Maret & 54 & 926.000 .000 \\
\hline \multicolumn{2}{|c|}{ Jumlah } & $\mathbf{2 5 6}$ & $\mathbf{4 . 5 7 6 . 5 0 0 . 0 0 0}$ \\
\hline
\end{tabular}

Sumber: Data per tanggal 21 A pril 2016 dari BRI Unit Soekarno-Hatta yang diolah. 
Tabel 2 menunjukkan BRI U nit Soekarno-Hatta selama tujuh bulan terakhir dalam penyaluran KUR Mikro telah membukukan perolehan senilai lebih dari 4,5 Milliar rupiah, dengan total nasabah 256 orang, dan persentase NPL (Non Performing Loan) sebesar 0\%. Artinya selama 7 bulan terakhir pelaksanaan KUR Mikro, nasabah BRI Unit Soekarno-Hatta tidak ada yang menunggak pembayaran angsuran KUR Mikro-nya.

Temuan dalam penelitian ini disandingkan dengan teori yang ada terkait implementasi kebijakan KUR Mikro oleh PT. B RI U nit Soekarno-H atta antara lain:

1. Isi K ebijakan KUR M ikro. Dilihat dari isi kebijakan, kebijakan KUR Mikro dinilai sangat baik. Aspek yang mendukung adalah terakomodirnya kepentingan pelaksana dan sasaran kebijakan, manfaat yang diterima berupa bantuan pembiayaan, sasaran kebijakan untuk peningkatan daya saing UMK M , letak pengambilan keputusan yang mutlak bagi bank pelaksana, dan profesionalisme $P T$. BRI selaku pelaksana kebijakan KUR Mikro yang memiliki sumberdaya yang sangat baik seperti dana, sarana-prasarana serta kredibilitas PT. BRI sebagai BUMN terbesar di Indonesia.

2. Lingkungan Kebijakan KUR Mikro, dilihat dari aspek lingkungan kebijakan juga dinilai baik. Aspek yang mendukung adalah kekuasaan PT. BRI dalam melaksanakan KUR M ikro yang bersifat mutlak, kepentingan PT. BRI telah terakomodir dengan didukung dengan strategi yang kuat. Tidak adanya unsur politis dalam pelaksanaan kebijakan KUR Mikro juga turut mendorong terlaksananya kebijakan KUR M ikro dengan baik. K arakter PT. BRI dan pemerintahan Bapak Ir. H. J oko Widodo yang menaruh konsentrasi terhadap perkembangan ekonomi mikro dan makro di Indonesia serta tingkat kepatuhan dan responsivitas UMKM juga dinilai sangat mendukung.
3. Kebijakan KUR Mikrodari pemerintah melalui PT. BRI membawa dampak yang positif bagi laju ekonomi dan usaha UM K M . Namun keterbatasan PT. $B R I$ dalam mengukur perkembangan skala usaha dari UMKM penerima KUR Mikro membutuhkan campur tangan pemerintah untuk tercapainya tujuan utama KUR Mikro sebagai kebijakan percepatan pengentasan kemiskinan.

4. Peran PT. Bank Rakyat Indonesia (Persero) Tbk Sebagai Pelaksana Kebijakan Pemerintah dan Lembaga Keuangan BUMN. Peran PT. BRI dalam penyaluran KUR Mikro dengan target yang tinggi akan meningkatkan resiko terjadinya kerugian akibat munculnya kredit macet yang berakibat pada kerugian pihak bank dan lembaga penjamin. Untuk menghindari maupun memperkecil resiko kredit yang mungkin terjadi, maka permohonan kredit harus dinilai oleh bank atas dasar syarat teknis bank sesuai profesionalisme lembaga perbankan.

\section{KESIMPULAN}

PT. BRI Unit Soekarno - Hatta dalam implementasi kebijakan $\mathrm{K}$ redit Usaha Rakyat Mikro yang ditinjau dari aspek isi dan lingkungan dari kebijakan menunjukkan hasil yang sangat baik. Faktor yang mendukung adalah karakteristik PT. BRI Persero Tbk yang merupakan profesional dibidang perbankan dapat memastikan jalannya proses pengucuran dana pinjaman K redit U saha Rakyat Mikro kepada target group U saha Mikro Kecil dan Menengah berjalan dengan sangat baik.

Namun yang menjadi permasalahan adalah keterbatasan PT. B RI Persero Tbk dalam melakukan kegiatan monitoring dan evaluasi atas pengentasan kemiskinan sesuai dengan tujuan dari Peraturan Presiden No. 15 Tahun 2010. Penelitian ini memunculkan temuan 
penting bahwa implementor kebijakan yang sangat kompeten tidak serta merta membawa kebijakan kepada tujuan utamanya, tanpa adanya sinergitas dengan pihak-pihak terkait yang lebih mampu mengukur pencapaian tujuan dari kebijakan pemerintah, dalam hal ini yaitu pengentasan kemiskinan.

$Y$ ang menjadi tugas pemerintah pusat dan daerah saat ini adalah memastikan kebijakan yang telah berjalan sangat baik tersebut dapat meraih tujuan utamanya yaitu untuk meningkatkan kelas Usaha M ikro K ecil dan M enengah secara khusus dan mempercepat pengentasan kemiskinan secara umum. Pemaksimalan lembaga pemerintah yang memegang peranan penting dalam proses monitoring dan evaluasi, yang menurut peneliti adalah jalan terbaik guna memaksimalkan tercapainya tujuan kebijakan percepatan penanggulangan kemiskinan yang tercantum dalam Peraturan Presiden N o 15 Tahun 2010.

\section{DAFTAR PUSTAKA}

Abdul Wahab, Solichin. 2008a. AnalisisKebijaksanaandariFormulas ikeImplementasiKebijaksanaan Negara, B umiA ksara, Jakarta.

Dunn, William. N. 2003. Analisis Kebijakan Publik. Y ogyakarta:Gadjah M Mada University Press

Dye, Thomas R. 2008. Understanding Public Policy. Pearson Education Inc., Upper Saddle River, New Jersey.

Grindle, Merilee S., (ed), 1980. Politics and Apolicy Implementation in the Third World, new jersey: Princetown University Press.

Hoogerwerf. 1983. IImu pemerintahan. Terjemahan R.L.L. Tobing. J akarta: Erlangga.

Intruksi Presiden No 1 tahun 2010 tentang percepatan prioritas pembangunan nasional tahun 2010
Intruksi Presiden No 3 Tahun 2010 tentang program pembangunan yang berkeadilan

Islamy, IIfan. 1992. Prinsip-prinsip Perumusan Kebijaksanaan Negara Edisi 2. Jakarta: B umi A ksara

K eban, Jeremias T. 2008. Enam Dimensi Strategis Administrasi Publik: Konsep, Teori dan Isu. Y ogyakarta : Penerbit Gava M edia.

Lucie Cerna. 2013. The Natureof PolicyChange and Implementation: A Review of Different Theoretical Approaches, Organization for economic co operation and development.

Miles, A. Michael Huberman, Johny Saldana. 2014. Qualitative Data Analysis, Arizona State University U nited States Of A merica.

Moleong, Lexy J. 2007. M etodologi Penelitian Kualitatif. Bandung, PT. Remaja Rosdakarya.

Nugroho, Riant. D. 2012. Kebijakan Publik, Formulasi, Implementasi dan Evaluasi. Jakarta, Elex M edia Computindo.

Pasolong, Harbani. 2008. Kepemimpinan Birokrasi. B andung : A lfabeta

Peraturan Presiden No 13 tahun 2009 tentang koordinasi penanggulangan kemiskinan.

Peraturan Presiden No 15 tahun 2010 tentang percepatan penanggulangan kemiskinan

Samodra, W ibawa., Y uyun . P dan A gus P. (1994). Evaluasi Kebijakan Publik. Jakarta: Raja Grafindo Persada

Solihin. 2008. Corporate Social Responsibility from charity to sustainibility. Salemba Empat, Jakarta.

Tachjan, H. 2006. Implementasi Kebijakan Publik, Bandung: AIPI $B$ andung-Puslit, KP2W Lemlit UNPAD.

Tangkilisan, Hessel Nogi S. 2003. Kebijakan Publik yang Membumi. Y ogyakarta:Y ayasan 
Pembaruan Aministrasi Publik

Indonesia (YPAPI) \& Lukman

Offset. 